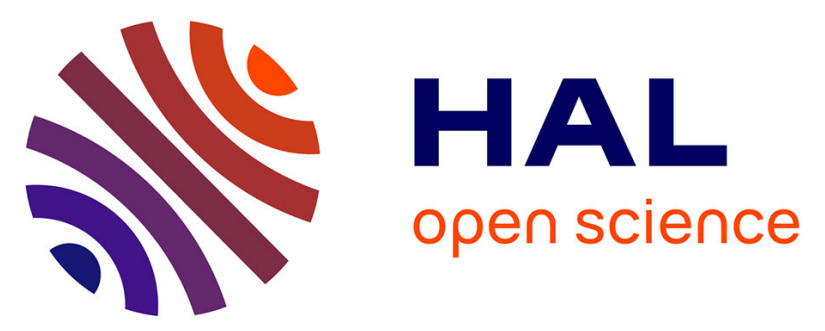

\title{
A dual biomimetic process for the selective aerobic oxidative coupling of primary amines using pyrogallol as a precatalyst. Isolation of the $[5+2]$ cycloaddition redox intermediates
}

Martine Largeron, Patrick Deschamps, Karim Hammad, Maurice-Bernard Fleury

\section{To cite this version:}

Martine Largeron, Patrick Deschamps, Karim Hammad, Maurice-Bernard Fleury. A dual biomimetic process for the selective aerobic oxidative coupling of primary amines using pyrogallol as a precatalyst. Isolation of the $[5+2]$ cycloaddition redox intermediates. Green Chemistry, 2020, 22 (6), pp.18941905. 10.1039/c9gc03992a . hal-02491888

\section{HAL Id: hal-02491888 \\ https://hal.science/hal-02491888}

Submitted on 9 Nov 2020

HAL is a multi-disciplinary open access archive for the deposit and dissemination of scientific research documents, whether they are published or not. The documents may come from teaching and research institutions in France or abroad, or from public or private research centers.
L'archive ouverte pluridisciplinaire HAL, est destinée au dépôt et à la diffusion de documents scientifiques de niveau recherche, publiés ou non, émanant des établissements d'enseignement et de recherche français ou étrangers, des laboratoires publics ou privés. 


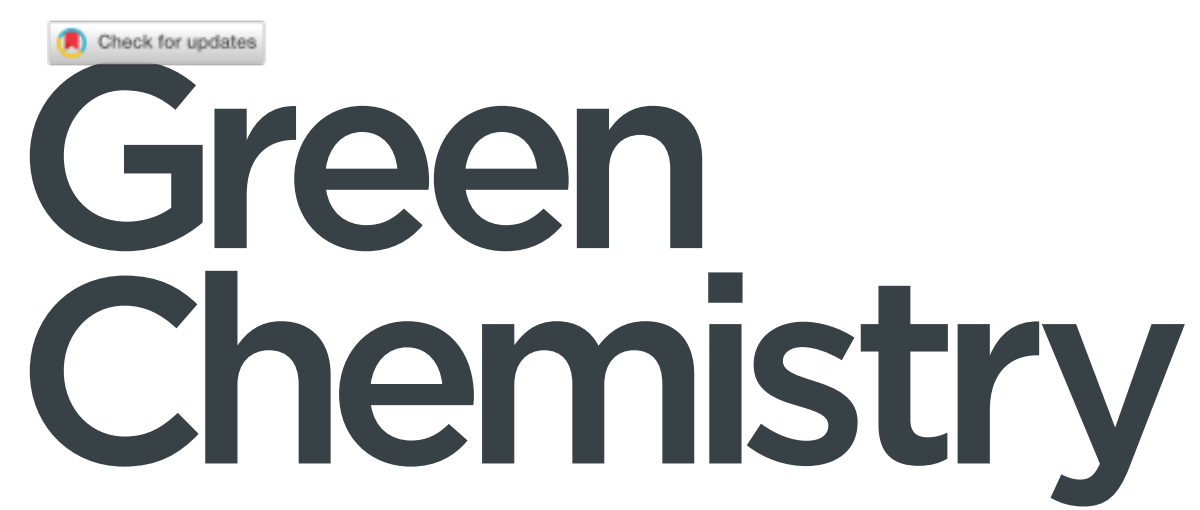

Cutting-edge research for a greener sustainable future

\section{Accepted Manuscript}

This article can be cited before page numbers have been issued, to do this please use: M. Largeron, P.

Deschamps, K. Hammad and M. Fleury, Green Chem., 2020, DOI: 10.1039/C9GC03992A.

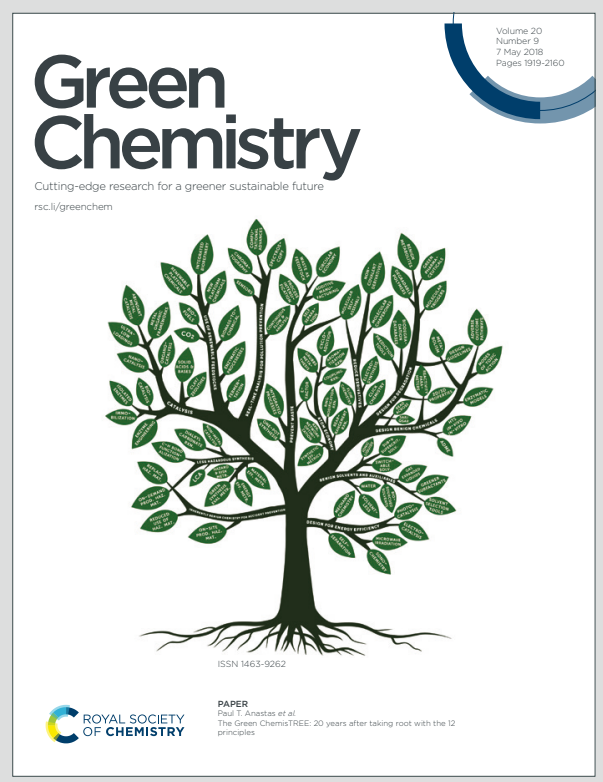

This is an Accepted Manuscript, which has been through the Royal Society of Chemistry peer review process and has been accepted for publication.

Accepted Manuscripts are published online shortly after acceptance, before technical editing, formatting and proof reading. Using this free service, authors can make their results available to the community, in citable form, before we publish the edited article. We will replace this Accepted Manuscript with the edited and formatted Advance Article as soon as it is available.

You can find more information about Accepted Manuscripts in the Information for Authors.

Please note that technical editing may introduce minor changes to the text and/or graphics, which may alter content. The journal's standard Terms \& Conditions and the Ethical guidelines still apply. In no event shall the Royal Society of Chemistry be held responsible for any errors or omissions in this Accepted Manuscript or any consequences arising from the use of any information it contains. 


\title{
ARTICLE
}

Received 00th January 20xx, Accepted 00th January 20xx DOI: $10.1039 / x 0 x \times 00000 x$

\section{A dual biomimetic process for the selective aerobic oxidative coupling of primary amines using pyrogallol as a precatalyst. Isolation of the [5+2] cycloaddition redox intermediates}

\author{
Martine Largeron, ${ }^{* a}$ Patrick Deschamps, ${ }^{\text {a Karim Hammad }}{ }^{\text {a }}$ and Maurice-Bernard Fleury a
}

\begin{abstract}
A bioinspired organocatalytic cascade reaction mimicking both purpurogallin biosynthesis and copper amine oxidases (CUAOs) activity is described, at room temperature under ambient air, for the activation of the $\alpha-\mathrm{C}-\mathrm{H}$ bond of primary amines. The reaction sequence uses low-cost commercially available pyrogallol as a precatalyst which undergoes an in situ oxidative self-processing step, resulting in its conversion into natural purpurogallin, a $[5+2]$ cycloaddition redox intermediate. This is further involved in the CuAOs-like transamination mechanism for producing, under single turnover, the active biomimetic organocatalyst which mediates the selective oxidative coupling of primary amines, including the nonactivated substrates of CuAOs. Without any metal cocatalyst or additives, the protocol gives access to cross-coupled imines as well as 1,2-disubstituted benzimidazoles. The isolation of not easily accessible [5+2] cycloaddition redox intermediates provides direct and clear evidence for the proposed dual biomimetic process.
\end{abstract}

\section{Introduction}

The concept of waste prevention is central, influencing all aspects of modern society. Due to the harmful effects of chemical waste on the environment, catalysis plays a major role in chemistry for achieving both environmental and economic objectives. By using catalysts to perform chemical transformations, the amounts of both reagents and waste generated are considerably reduced. In particular, biocatalysis, which refers to the use of enzymes for synthetic applications, and bioinspired catalysis, which involves chemical species mimicking certain features of enzymes, have been identified as green methodologies by taking the benefits of catalysis with significant improvements. ${ }^{1}$ These naturally derived catalysts are generally highly active under mild conditions, at ambient temperature and pressure, and exhibit high selectivity. Given that they are found in biological systems, biocatalysts are relatively renewable, nontoxic and biodegradable. However, they may not catalyse the reaction with non-natural substrates or not yield the desired products. This activity gap has inspired chemists to introduce artificial cofactors into protein scaffolds leading to the development of artificial enzymes, ${ }^{2}$ but also to design bioinspired catalysts. ${ }^{3}$ These small molecules, which are devoid of protein scaffolds, have some advantages over naturally occurring biocatalysts as they may expand the scope of possible substrates and increase the scale of production. They are also useful for environmentally friendly catalytic chemistry, where it is important to avoid the use of toxic or expensive metal reagents, energy-consuming processing steps and undesirable solvents.
Copper amine oxidases (CuAOs) are a family of metalloenzymes which is involved in the metabolism of amines. ${ }^{4}$ CuAOs couple the selective oxidation of unbranched primary amines to aldehydes with the reduction of dioxygen to hydrogen peroxide, through the synergistic action of a quinone-based organic cofactor, 2,4,5trihydroxyphenylalanine quinone or topaquinone (TPQ) and a copper ion, which is not directly implicated in the amine oxidation step (Scheme 1). ${ }^{5-7}$

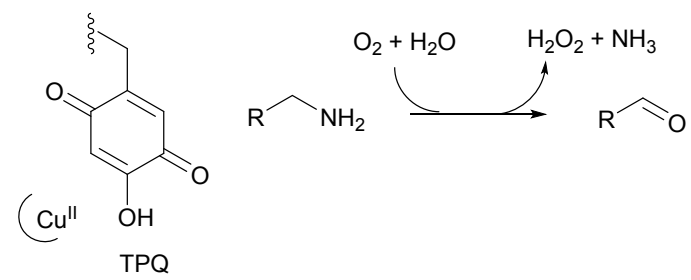

Scheme 1 Selective aerobic oxidation of primary amines to aldehydes mediated by CuAOs cofactors.

CuAOs have inspired considerable efforts to mimic their reactivity with synthetic quinone catalysts, earlier to demonstrate the transamination mechanism by which these enzymes operate, ${ }^{8}$ while recent studies have focused on synthetic applications. ${ }^{9}$ Thus, the aerobic oxidation of amines has been achieved with biomimetic or bioinspired quinone-based catalysts to accomplish crossimination, ${ }^{10}$ oxidative $\quad \alpha-\mathrm{C}-\mathrm{H} \quad$ functionalization, ${ }^{11} \quad$ crossdehydrogenative coupling, ${ }^{12}$ deaminative cross-coupling and $\mathrm{N}$ nitrosation of amines. ${ }^{13}$ Biomimetic catalytic systems promote selective aerobic oxidation of unbranched primary amines, at room

aUniversité de Paris, CiTCoM, UMR 8038, CNRS, F-75006 Paris, France.

E-mail : martine.largeron@parisdescartes.fr. https://orcid.org/0000-0002-1725-8118

†Electronic Supplementary Information (ESI) available: [details of any supplementary information available should be included here]. See DOI: 10.1039/x0xx00000x 


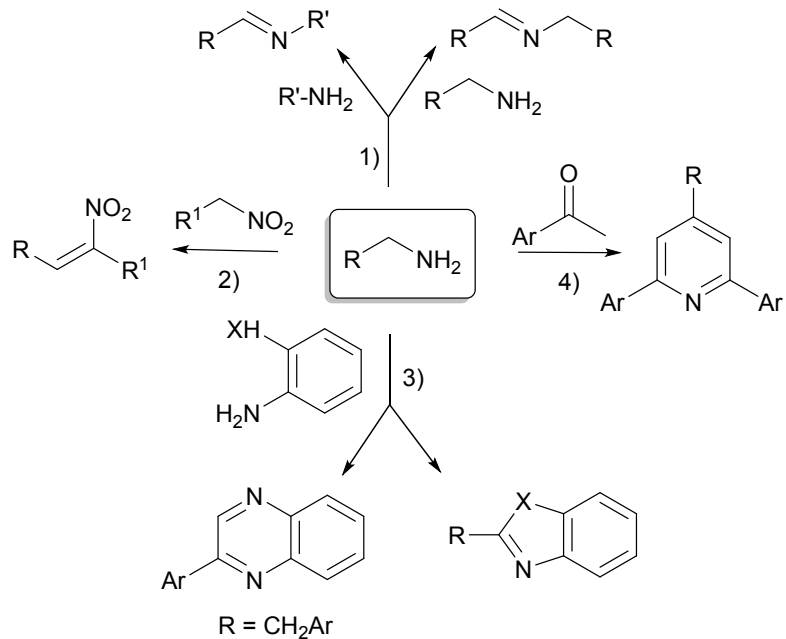

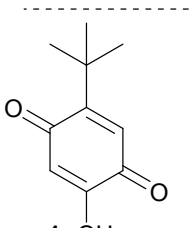

$1 \mathrm{OH}$

Stahl et al ${ }^{10 a}$

1): $\mathrm{MeCN}, \mathrm{O}_{2}$ balloon rt, $20 \mathrm{~h}$<smiles>CC(=O)C1=C(O)C(=N)C(=O)C=C1</smiles>

Largeron et al ${ }^{10 \mathrm{~b}, \mathrm{~d}, 11 \mathrm{a}, \mathrm{c}}$

1): $\mathrm{MeOH}, \mathrm{Cu}(\mathrm{OAc})_{2} / \mathrm{air}$

rt, $10 \mathrm{~h}$

3): $\mathrm{X}=\mathrm{NR}, \mathrm{MeOH}, \mathrm{Cu}(\mathrm{Br})_{2} / \mathrm{ai}$

$45^{\circ} \mathrm{C}, 24 \mathrm{~h}$<smiles>[R]C1=CC(=O)C(=O)c2ccccc21</smiles>

Oh et $\mathrm{a} \mathbf{1}^{10 \mathrm{e}, 13}$ 1) $4: R^{\prime}=P h$ $\mathrm{MeCN}, \mathrm{O}_{2}$ balloon $\mathrm{Cu}(\mathrm{OAc})_{2}$, rt, $24 \mathrm{~h}$ 2): $5: R^{\prime}=4-F P h$ air, $80^{\circ} \mathrm{C}, 12 \mathrm{~h}$

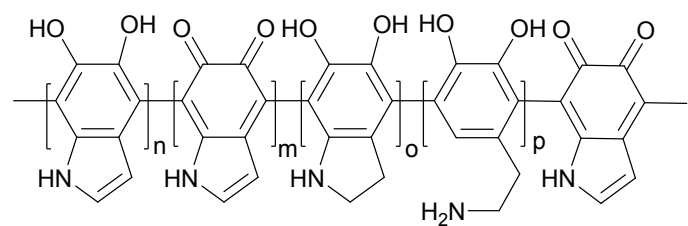

Vijay Kumar et al ${ }^{11 \mathrm{f}}$ 3): $\mathrm{H}_{2} \mathrm{O}, \mathrm{O}_{2}$ balloon, $24 \mathrm{~h}$

8 (Polydopamine) $\mathrm{X}=\mathrm{NH}, \mathrm{TsOH}, 60^{\circ} \mathrm{C}$<smiles>[R]c1cc(C=C)cc(C2=C(C(C)C)C(=O)C(C(C)C)=CC2=O)c1</smiles><smiles>C=CC1=CO[Al-]2(N=C1)OC=NC=C2C=C</smiles><smiles>[R]c1cc(C2=C(C(C)(C)C)C(=O)C(C(C)C)=CC2=O)cc([R])c1N</smiles>

1): $\mathrm{MeCN}, \mathrm{O}_{2}$ stream, rt, 30min

Scheme 2 Selective aerobic oxidation of unbranched primary amines mediated by biomimetic quinone-based catalysts 1-9. Examples of synthetic applications. temperature, without reacting with secondary and tertiary and follow a transamination mechanism reminsisent of that repłore?d for natural CuAOs (Scheme 2), ${ }^{10}$ while bioinspired catalysts surpass the activity of natural CuAOs by increasing the scope of substrates to $\alpha$-branched, ${ }^{12 a, 14}$ secondary ${ }^{12 a, 13,15}$ and tertiary amines ${ }^{12,13}$ following abiological pathways. Nevertheless, the procedures still suffer some drawbacks: 1) the majority of biomimetic catalysts has to be synthesized prior use affecting the economics as well as the ecofriendly nature of the methods; 2 ) when commercially available, the quinone catalysts are often expensive or require the cooperative action of additives such as metal co-catalyst. This may constitute a problem in the synthesis of medicinally relevant compounds due to the contamination of the final products by metal residues; 3 ) very few quinone-catalysed amine oxidation protocols are applicable to non-activated primary aliphatic amines, the natural substrates for CuAOs.

Recently, the concept of "second-order" biomimicry has been defined to describe a system in which in situ modification or processing of pre-catalyst components affords the active biomimetic catalyst, as opposed to "first-order" biomimicry, in which the active biomimetic catalyst is synthesized directly. ${ }^{16}$ Obviously, "secondorder" biomimicry introduces new opportunities for the discovery of efficient active biomimetic organocatalysts generated in situ from simple and low-cost precursors, without turning to chemical synthesis.

In a preliminary communication, we have recently reported the first example of "second-order" biomimicry for the selective aerobic oxidation of unbranched primary amines to imines under exceptionally mild conditions (Scheme 3). ${ }^{17}$

Purpurogallin biosynthesis mimicry

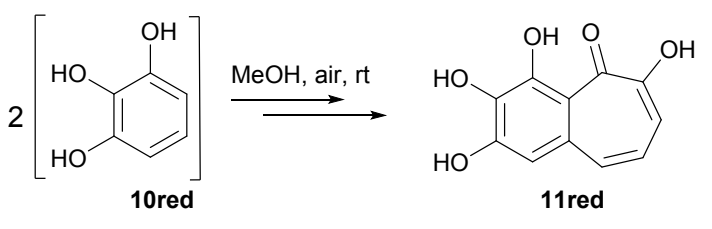

Pyrogallol precatalyst

Purpurogallin intermediate

$$
\downarrow \downarrow \begin{aligned}
& \text { first single } \\
& \text { turnover }
\end{aligned}
$$

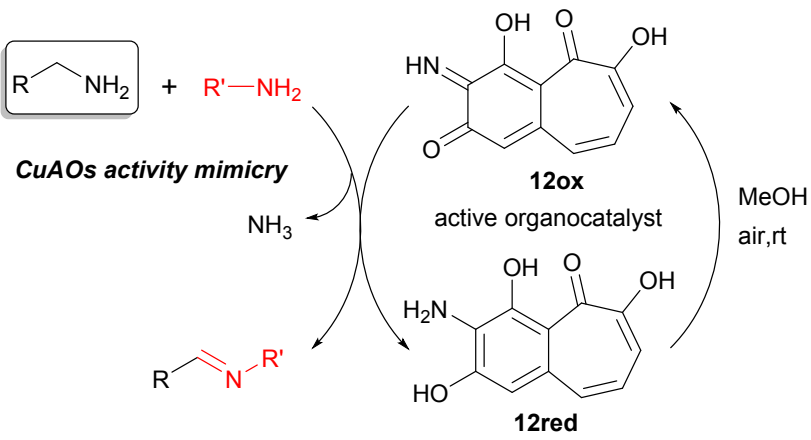

Scheme 3 Proposed "second-order" biomimicry for the aerobic oxidative cross-coupling of primary amines to imines.

This one-pot cascade reaction sequence, which mimics both purpurogallin biosynthesis and CuAOs activity, starts from commercially available low-cost pyrogallol 10red as a precatalyst, allowing in situ formation of not easily accessible natural 
purpurogallin (2,3,4,6-tetrahydroxy-5H-benzocyclohepten-5-one) 11red. This is further engaged in the CuAOs-like transamination mechanism affording, under single turnover, the active biomimetic organocatalyst 120x, which mediates the oxidative coupling of primary amines under ambient air. However, the proposed reaction pathway was only based on control experiments and we were aware that a real proof of the transient presence of purpurogallin was highly desirable. In this full paper, we present the results of new experiments aimed at validating the "second-order" biomimetic process, through the isolation of [5+2] cycloaddition redox intermediates including purpurogallin.

\section{Results and discussion}

The limited availability of natural purpurogallin 11red led us to examine its well-established biosynthesis, which involves the oxidative dimerization of pyrogallol 10red generated from gallic acid 13. Two molecules of o-quinone are engaged in a $[5+2]$ cycloaddition reaction affording, after tautomerization reaction, the benzotropolone scaffold 14 (Scheme 4). Attack of water on the carbonyl bridge of $\mathbf{1 4}$ yields a carboxylic intermediate, which is prone to further oxidation and decarboxylation, leading to purpurogallin 11red. ${ }^{18}$ Accordingly, we chose to utilize 10red as a precatalyst for generating 11red in situ.

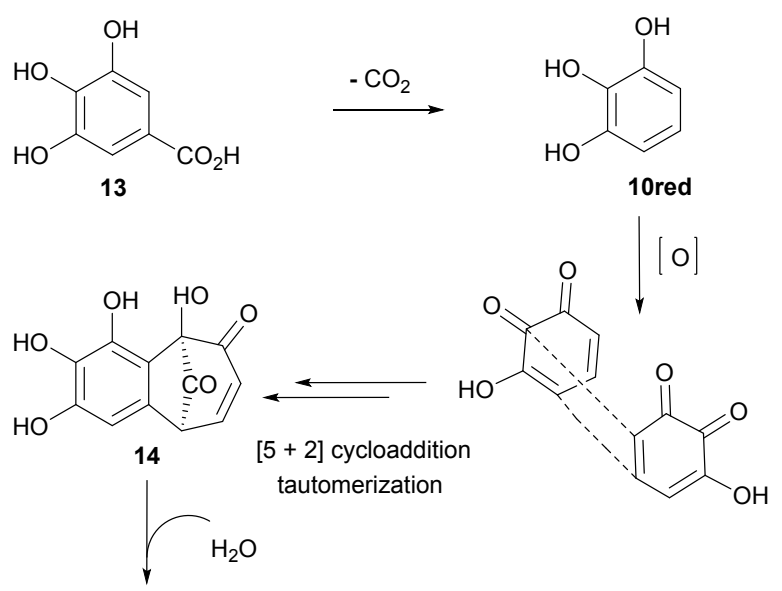<smiles>O=C(O)[C@H]1C=CC(O)=C(O)c2c1cc(O)c(O)c2O</smiles>

Scheme 4 Established biosynthesis of purpurogallin 11red.

Early attempts to isolate 11red as a key intermediate in the proposed dual bioinspired organocatalytic process were performed using benzylamine $\mathbf{1 5}$ as the amine substrate. Previous optimization studies had revealed that a combination of one equivalent of benzylamine with 0.04 equivalent of 10red $(4 \mathrm{~mol} \%$ allowing the generation of $2 \mathrm{~mol} \%$ of $11 \mathrm{red}$ ) was ideal for the reaction. Complete conversion of 15 into $\mathrm{N}$-benzylidene-benzylamine 16 (see Scheme 7) was then observed after $24 \mathrm{~h}$, at room temperature, under ambient air, using $\mathrm{MeOH}$ as the solvent. ${ }^{17}$ Under these experimental conditions, the reaction medium could contain no more than $2 \mathrm{~mol} \%$

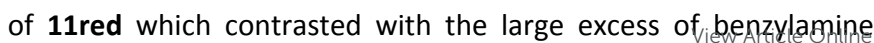
utilized. Obviously, the low amount of 19red formed in situ, combined with its very low solubility in organic media, would create serious problems in the course of the isolation procedure, especially during the column chromatography. So, we envisioned some modifications of our initial protocol. First, we changed 10red to 17red, because the isolation of the corresponding purpurogallin analogue $\mathbf{1 8} \mathrm{red}$ should be facilitated by the presence of two benzyl groups (Scheme 5). To ensure that 17red and 10red behaved similarly, the aerobic catalytic oxidation of benzylamine $\mathbf{1 5}$ was performed under the optimal reaction conditions, ${ }^{17}$ using 17red as the starting material. The reaction proceeded smoothly and full conversion into imine $\mathbf{1 6}$ could be attained after a prolonged reaction time of $36 \mathrm{~h}$. Second, we decided to modify the molecular ratio between 17red and amine $\mathbf{1 5}$ to facilitate the isolation of purpurogallin-like intermediate 18red from the bulk solution. Accordingly, the reaction was carried out in $\mathrm{MeOH}$, at room temperature, under ambient air, in the presence of one equivalent of $\mathbf{1 5}$ and 0.25 equivalent of $\mathbf{1 7}$ red. When $30 \%$ of $\mathbf{1 5}$ was converted to imine 16 , the reaction was stopped by addition of dry ice. After evaporation of the solvent and column chromatography, two [5+2] cycloaddition new redox products 18 red and 19red were isolated in 5 and $15 \%$ yields, respectively (Scheme 5 ).
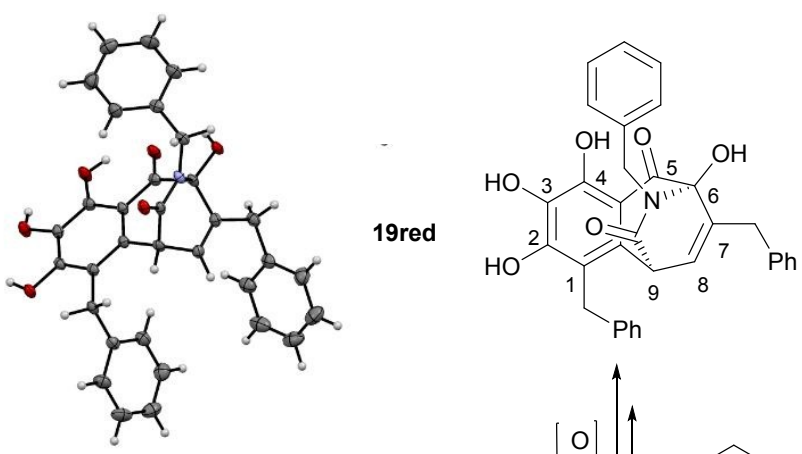

$$
[\mathrm{O}] \uparrow_{\mathrm{H}_{2} \mathrm{~N}}^{\sim} \underset{15}{\mathrm{Ph}}
$$<smiles>Oc1ccc(Cc2ccccc2)c(O)c1O</smiles><smiles>O=C1C(Cc2ccccc2)=C[C@H]2O[C@]1(O)c1c(O)c(O)c(O)c(Cc3ccccc3)c12</smiles><smiles>O=C(O)CCCCCCCCC(=O)O</smiles><smiles>CC(C)(C)C(C)(C)C</smiles>

Scheme 5 [5 +2 ] cycloaddition redox products 18 red and 19red isolated during the aerobic oxidation of benzylamine mediated by 17red. Ortep view of 19red. Displacement ellipsoids are drawn at the $50 \%$ probability level. 
The structure of 18red was established on the basis of extensive spectroscopic data including 2D NMR experiments (See Experimental and ESI), while the X-Ray crystallographic data undoubtedly confirmed the proposed structure 19red as a single diastereomer of relative configuration $6 R, 9 R$ (Scheme 5 and Table S1).

From these results, it could be deduced that [5+2] cycloaddition redox intermediates could be formed in $\mathrm{MeOH}$, under ambient air, starting from a pyrogallol derivative, in the presence of benzylamine. Note pyrogallol 17red was stable in methanol under ambient aerobic conditions and did not produce spontaneously the aerobic dimerization product, purpurogallin 18red. The presence of benzylamine was required for producing the monoanionic form of pyrogallol 17red (pKa around 9) which was further oxidized to the orthoquinone redox species. Two molecules of orthoquinone were further engaged in the [5+2] cycloaddition reaction initiating the formation of purpurogallin 18red. The latter would result from a nucleophilic attack of intermediate 20 (Scheme 5) by water, oxidation and decarboxylation steps, following a way which parallels that established for purpurogallin biosynthesis (Scheme 4). Interestingly, another [5+2] cycloaddition reaction product 19red was also isolated. Its formation very likely would arise from a competitive nucleophilic attack of benzylamine $\mathbf{1 5}$ on the carbonyl group in the five-membered ring of intermediate $\mathbf{2 0}$, resulting in a ring-opening reaction. ${ }^{19}$ Subsequent oxidation step involving amide intermediate $\mathbf{2 1}$ would afford $\mathbf{2 2}$ which would rearrange into compound 19red as proposed in Scheme 6.

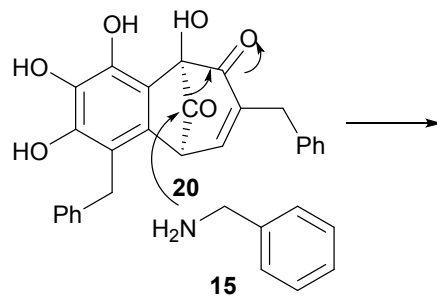<smiles>CCCc1c(O)c(O)c(O)c2c1[C@H](C(=O)NCc1ccccc1)C=C(Cc1ccccc1)C(O)=C2O</smiles><smiles>O=C1N(c2ccccc2)C(=O)C2(O)C(c3ccccc3)C=C(Cc3ccccc3)C1(O)C2c1ccccc1</smiles><smiles></smiles><smiles>O=C1C(Cc2ccccc2)=CC(C(=O)Cc2ccccc2)(C(=O)NCc2ccccc2)c2c(O)c(O)c(O)c(O)c21</smiles>

Scheme 6 Proposed reaction mechanism for the formation of compound 19red.

At this stage, note that both compounds 18red and 19red displayed two features that we have previously observed with redox precursors of bioinspired quinone-based catalysts of the same series: first, the presence of a carbonyl group adjacent to the pyrogallol moiety; second, the presence of an active hydroxyl group (red $\mathrm{OH}$ in Scheme 7). This was found to be an essential component of the catalytic activity associated with enzymatic ${ }^{7 a, 7 d, 8}$ and non-enzymatic catalytic systems ${ }^{9 c, 10 a-d, 20}$ through the formation of a highly reactive
$\mathrm{H}$-bonded cyclic transition state (CTS) (see Scheme 8) viNotericweshad also shown that the aerobic oxidation of 2-ahilide produced a poorly reactive $o$-iminoquinone catalyst, that mainly decomposed to melanin-like polymers, giving only $5 \%$ of imine $16 .{ }^{17}$ When compared to highly reactive $o$-iminoquinone $\mathbf{2}$ (Scheme 2 ), this result confirmed the essential role of the acetyl group for successful operation of the catalytic process. ${ }^{20 c}$
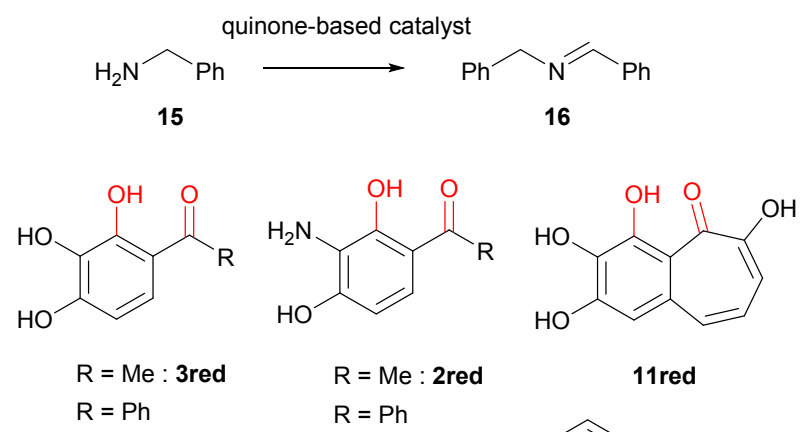<smiles>O=c1c(O)c(Cc2ccccc2)ccc2c(Cc3ccccc3)c(O)c(O)c(O)c12</smiles>

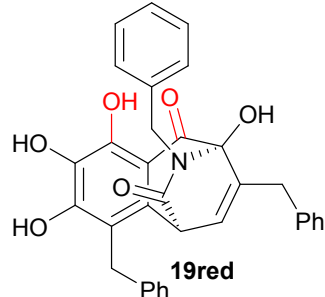

Scheme 7 Structural analogy between the redox precursors of bioinspired active quinone-based catalysts and products $18 \mathrm{red}$ and 19red.

Therefore, we were encouraged to consider that not only 18red but also 19red, could be involved in the aerobic catalytic oxidation of benzylamine 15 to imine 16 . Consequently, to clarify their respective role in supporting the catalytic efficiency, each compound ( 2 mol\%) was separately tested in the presence of $\mathbf{1 5}$, under the optimal reaction conditions.

After $36 \mathrm{~h}$, almost full conversion (87\%) of $\mathbf{1 5}$ into $\mathbf{1 6}$ could be observed starting from 18red, while the benzylamine conversion did not exceed $40 \%$ using $19 \mathrm{red}$. As a consequence, $18 \mathrm{red}$ proved to be the better candidate for generating the quinone-based catalyst responsible for the high catalytic efficiency observed when compound 17red was used as the starting material (full conversion after $36 \mathrm{~h}$ ). Then, the continuously low concentration of the in situ generated o-quinone species $\mathbf{1 8 0 x}$ (see Scheme 8) should protect it against the competitive formation of melanin-like polymers. Finally, 18red exhibited a behaviour close to that already observed with natural purpurogallin 11red. ${ }^{17}$ Taking all together, 18red was considered as the most effective [5+2] cycloaddition intermediate in the bioinspired aerobic oxidative cascade reaction sequence allowing the oxidation of primary amines to imines.

The second part of the reaction sequence concerns the CuAOs activity mimicry. Once again, we showed that $\alpha$-branched primary amines such as sec-benzylamine were poor substrates for the biomimetic catalytic process (5-10\% conversion), while secondary amines were not reactive at all. These results were fully in agreement with the enzymatic transamination mechanism which has been well 
established through the utilization of bioinspired quinone-based catalytic systems (Scheme 8).8,10,14a,20a,c
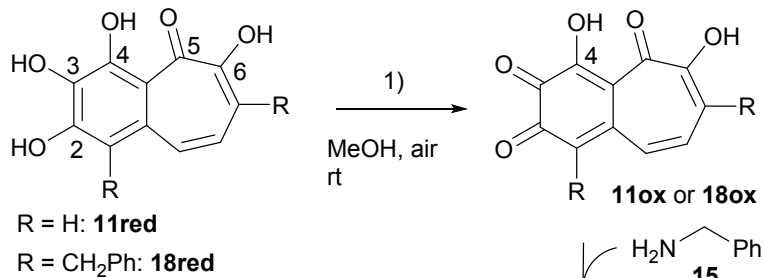

2) $\overbrace{\text { single turnover }} \overbrace{\mathrm{H}_{2} \mathrm{O}}^{\mathrm{H}_{2} \mathrm{~N}_{15}^{\mathrm{Ph}}}$

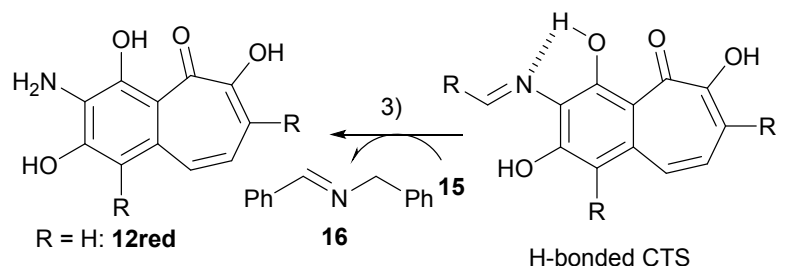
$\mathrm{R}=\mathrm{CH}_{2} \mathrm{Ph}: \mathbf{2 3 r e d}$ air, rt 4)<smiles>[R]C1=c2ccc([R])c(O)c(=O)c2=C(O)C(=N)C1=O</smiles>

$\mathrm{R}=\mathrm{H}: \mathbf{1 2 0 x}$

$\mathrm{R}=\mathrm{CH}_{2} \mathrm{Ph}: 230 x$

Scheme 8 Proposed transamination mechanism for the aerobic oxidation of primary amines to imines mediated by 0 -iminoquinone active organocatalyst $\mathbf{1 2 0 x}$ or $\mathbf{2 3 0 x}$.

The presence of the benzotropolone scaffold not only favoured attack of the amine at the 3-position of the generated o-quinone species 11ox or 180x (Scheme 8, step 1), but also facilitated $\alpha$-proton abstraction and the subsequent electron flow from the $\alpha$-carbon to the o-quinone moiety, which aromatizes to a Schiff base intermediate (Scheme 8, step 2). Crucial also was the presence of an active hydroxyl group at the 4-position, which was previously proved to be an essential requirement for the successful operation of the catalytic process in the studied series. ${ }^{9 c, 10 a-d, 20}$ The activation of the imine function for further nucleophilic attack by the amine $\mathbf{1 5}$, leading to the extrusion of imine $\mathbf{1 6}$ (Scheme 8 , step 3), was provided by the intramolecular hydrogen bond between the 4-hydroxyl group and the imine nitrogen, generating a highly reactive $\mathrm{H}$-bonded CTS. ${ }^{9 c, 20 c}$ Similar effects of phenolic hydroxyl groups on the reactivity of ketimine derivatives have been previously reported. ${ }^{21}$ Aerobic oxidation of the generated aminophenol form 12red or 23red after single turnover generated the active $o$-iminoquinone organocatalyst (Scheme 8, step 4), which can undergo transamination with benzylamine substrate (Scheme 8 , step 5 ) and close the catalytic cycle by passing 110x or 180x.

The bioinspired organocatalytic cascade reaction reported here allows the selective oxidation of primary amines to imines under ambient air, at room temperature, without any metal cocatalyst or additives. These environmentally mild conditions are particularly

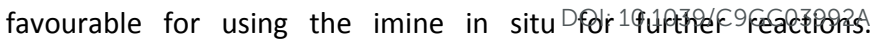
Accordingly, we have focused on two synthetic applications, first, the oxidative cross-coupling of primary amines, second, the synthesis of 1,2-disubstituted benzimidazoles.

The oxidative cross-coupling of primary amines is known to be a challenging transformation as self-coupling is usually preferred. Recently, selective formation of cross-coupled imines has been reported, but the procedures generally require elevated temperature, oxygen pressure, metal cocatalyst, additive or problematic solvent. ${ }^{10,22}$ Our dual bioinspired cascade reaction sequence proved to be effective for producing cross-coupling imines. The optimized reaction conditions we had previously reported ${ }^{17}$ were applied by mixing two primary amines in a ratio 1:1 upon increasing pyrogallol 11red loading to $10 \mathrm{~mol} \%$ (generating $5 \mathrm{~mol} \%$ of active organocatalyst 120x), in $\mathrm{MeOH}$, at room temperature, under ambient air. Note $\mathrm{MeOH}$ was found to be the best solvent for the aerobic oxidative coupling of primary amines to imines because it provided the ideal balance of $110 x$ (or 120x) solvation by enhancing the electrophilicity of the quinonoid moiety and reaction rate. ${ }^{20,23}$ Although $\mathrm{MeOH}$ was initially considered as problematic according to Safety, Health and Environment (SH\&E) criteria, it was finally ranked as recommended in the CHEM21 solvent guide. ${ }^{24}$ The result of the 120x-mediated aerobic cross-coupling of primary amines is illustrated in Table 1 (See Experimental). The reaction is quite effective for various sec-primary amines $24 a-I$ and unbranched aliphatic primary amines $\mathbf{2 4 m}$ and $\mathbf{2 4 n}$. A single colourless crystal of imine 24j suitable for $\mathrm{X}$-ray diffraction analysis was obtained from $\mathrm{MeOH}$ (Chart 1 and Table S1). Complete selectivity was observed except for cross-coupled imines $\mathbf{2 4 m}$ and $\mathbf{2 4 n}$ since the analysis of the reaction mixture by ${ }^{1} \mathrm{H}$ NMR revealed the presence of $7 \%$ of the corresponding homocoupled imine (See ESI). However, with poor nucleophilic 4-methoxyaniline, the conversion did not exceed $68 \%$ after $60 \mathrm{~h}$, leading to the cross-coupled imine $\mathbf{2 4 0}$ in only $55 \%$ isolated yield.

More challenging, the possibility of expanding the reaction scope to the synthesis of scarcely stable aliphatic imines has also been explored. Due to their isomerization into enamine tautomer, which decomposes under ambient air, the generated alkylimines have been generally trapped in situ for further reactions. ${ }^{10 \mathrm{~d}, 11 \mathrm{~g}}$ So, we have performed the aerobic oxidative cross-coupling of a range of nonactivated primary aliphatic amines with $\mathrm{N}$-substituted-oaminoanilines as in situ imine trap. This reaction led to 1,2disubstituted benzimidazoles which are privileged and significant structural components of pharmaceuticals..$^{25}$ For this reason, numerous strategies have been developed for the regiocontrolled synthesis of 1,2-disubstituted benzimidazoles. ${ }^{26}$ In particular, the catalytic oxidative coupling of amines has provided a straightforward protocol to synthesize substituted benzimidazoles derivatives through the variation of both commercially available cyclocondensation partners. ${ }^{11 a, c, d, f, 27}$ However, with only few exceptions, ${ }^{11 a, c, d}$ the molecular diversity is limited to derivatives bearing benzylic or allylic substituents at the 2-position of the benzimidazole framework, because of the difficulty of oxidizing nonactivated primary amines. 


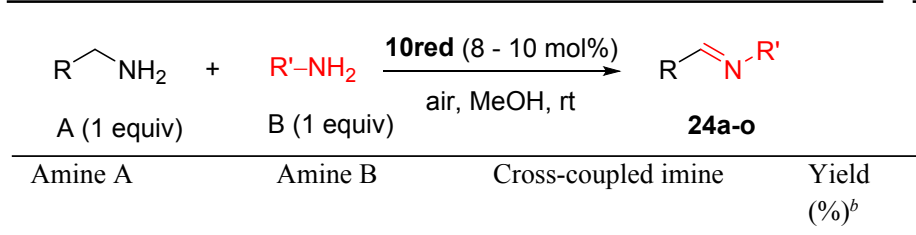

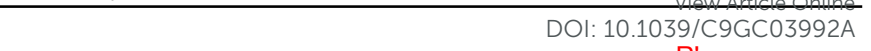

$\mathrm{NH}_{2}$

$\overbrace{\mathrm{Cl}}^{\mathrm{NH}_{2}}$

87

$\overbrace{S} \mathrm{NH}_{2}$<smiles>CCC(N)CC</smiles><smiles>CCC(CC)N/C=C/c1cccs1</smiles>

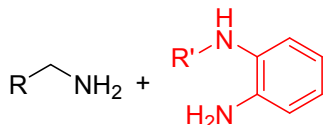
$\underset{\text { 10red }(10 \mathrm{~mol} \%)}{\stackrel{\text { air } \mathrm{MeOH}, 45-60^{\circ} \mathrm{C}}{ }}$<smiles>[R]c1nc2ccccc2n1[R]</smiles>
A (1 equiv) $\quad B$ (1 equiv)

25a-o

Amine $\mathrm{A}$

$\curvearrowright \mathrm{NH}_{2}$<smiles>CNc1ccccc1N</smiles><smiles>Cn1c(CCc2ccccc2)nc2ccccc21</smiles>

$\overbrace{\mathrm{NH}_{2}}$<smiles>CC(N)c1ccccc1</smiles><smiles>Cc1ccc(C=NC(C)c2ccccc2)cc1</smiles><smiles>Cc1ccc(CN)cc1</smiles><smiles>NC1Cc2ccccc2C1</smiles><smiles>Cc1ccc(/C=N/C2Cc3ccccc3C2)cc1</smiles>

90<smiles>NCc1ccc(Cl)cc1Cl</smiles><smiles>Clc1ccc(/C=N/C2Cc3ccccc3C2)c(Cl)c1</smiles>

$24 k$

80<smiles>CCC(C)CN</smiles>

241<smiles>NCc1ccc2c(c1)OCO2</smiles><smiles>NC1Cc2ccccc2C1</smiles><smiles>C(=N/C1Cc2ccccc2C1)\c1ccc2c(c1)OCO2</smiles>
89<smiles>CC(C)(C)CN</smiles><smiles>CNc1ccccc1N</smiles><smiles>CCCCCc1nc2ccccc2n1C</smiles>

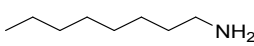<smiles>CNc1ccccc1N</smiles><smiles>CC(C)CCN</smiles><smiles>CNc1ccccc1N</smiles><smiles>CC(C)Cc1nc2ccccc2n1C</smiles><smiles>Cc1ccc(/C=N/CC2CCCCC2)cc1</smiles>

$24 m$ $93^{c}$ $\mathrm{MeO}_{\mathrm{NH}_{2}}$<smiles>CCCCCC=NCc1ccc(OC)cc1</smiles><smiles>Cc1ccc(CN)cc1</smiles><smiles>COc1ccc(/C=N/c2ccc(C)cc2)cc1</smiles>

${ }^{a} 8 \mathrm{~mol} \%$ of 10 red affording $4 \mathrm{~mol} \%$ of $\mathbf{1 2 0 x}$, rt, $100 \%$ conversion, reaction times: $24 \mathrm{~h}$ for $\mathbf{2 4 a - c}, \mathbf{2 4 e}, \mathbf{2 4 f}, \mathbf{2 4 m}$ and $\mathbf{2 4 n}$; $48 \mathrm{~h}$ for $\mathbf{2 4 d}$ and $60 \mathrm{~h}$ for $\mathbf{2 4 g - I}$ and 24o; additional aliquot of 10red ( $2 \mathrm{~mol} \%)$ was added after $24 \mathrm{~h} .{ }^{b}$ Isolated yields after column chromatography. ${ }^{c}$ Yields of the cross-coupled imine were determined by ${ }^{1} \mathrm{H}$ NMR. ${ }^{d} 68 \%$ conversion.

a $8 \mathrm{~mol} \%$ of 10red affording $4 \mathrm{~mol} \%$ of $\mathbf{1 2 0 x}, 100 \%$ conversion, reaction times $60 \mathrm{~h}, 60^{\circ} \mathrm{C}$ for $25 \mathrm{a}-\mathrm{I} ; 45^{\circ} \mathrm{C}$ for $\mathbf{2 5 m - 0}$; additional aliquot of 10red (2 mol\%) was added after $24 \mathrm{~h} .{ }^{b}$ Yields of the isolated product. ${ }^{7} 72 \mathrm{~h}$ 
Under the optimized reaction conditions previously reported, ${ }^{17}$ but at a slightly more elevated temperature of $60^{\circ} \mathrm{C}$, the organocatalyst $120 x$ was sufficiently reactive to activate the $\alpha-C-H$ bond of diverse non-activated primary aliphatic amines to give 1,2disubstitued benzimidazoles 25a-j in good isolated yields (Table 2 and Experimental). A single colourless crystal of benzimidazole 25d suitable for X-ray diffraction analysis was obtained from the chloroform/petroleum ether solvent system (Chart 1 and Table S1). Note this reaction was unsuccessful in the absence of $\mathrm{Cu}$ (II) cooperative catalyst when $\mathbf{2}$ was used as the sole organocatalyst. ${ }^{11 \mathrm{c}}$ As previously reported for catalysed aerobic oxidation of nonactivated alcohol, ${ }^{28}$ a decreased reactivity for sterically constrained $\beta$-branched alkylamines was observed affording the benzimidazoles 25k and $25 \mathrm{I}$ in 52 and $40 \%$ yields, respectively. As expected, the procedure could also be applied to common benzylic amines including heterocyclic amines containing a sulphur or oxygen atom which gave 1,2-disubstituted benzimidazoles $25 \mathrm{n}$ and $\mathbf{2 5 0}$ in good yields, after a prolonged reaction time of $72 \mathrm{~h}$.

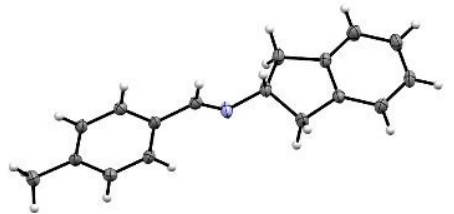

$24 \mathbf{j}$

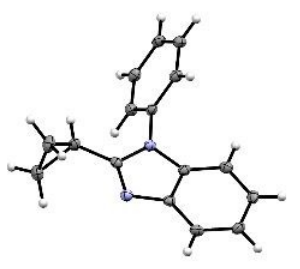

25d
Chart 1 Ortep views of imine $\mathbf{2 4 j}$ and 1,2-benzimidazole $\mathbf{2 5 d}$ Displacement ellipsoids are drawn at the $50 \%$ probability level.

Finally, cross-coupled imines $\mathbf{2 4 a - 0}$ were obtained through the transamination mechanism reported in Scheme 8 , yielding the homocoupled imine intermediate, which was progressively consumed in favour of the cross-coupled imine through dynamic transimination (Scheme 9, path 1). ${ }^{10,17}$ Its formation could be driven by continuous oxidation of the extruded primary amine $\mathrm{R}-\mathrm{CH}_{2}-\mathrm{NH}_{2}$ (self-sorting step) which was re-engaged in the transamination mechanism. So, just one equivalent of each amine was sufficient to achieve exclusive formation of the cross-coupled imine product. This oxidative strategy, known as oxidative self-sorting, has extensively been utilized to obtain thermodynamically disfavoured products. ${ }^{29}$ In the presence of $o$-aminoanilines, the resulting cross-coupled imines were engaged in cyclocondensation and oxidation reaction steps to furnish 1,2-disubstituted benzimidazoles 25a-o (Scheme 9, path 2).

\section{Conclusion}

New information about the reaction mechanism of an organocatalytic cascade reaction for the activation of the $\alpha-\mathrm{C}-\mathrm{H}$ bond of primary amines are disclosed through the isolation of [5+2] cycloaddition purpurogallin-like intermediates. The one pot protocol, mimicking both purpurogallin biosynthesis and CuAOs activity, utilizes inexpensive commercially available pyrogallol precatalyst, for delivering in situ, under ambient air, at room temperature, low loadings of the active biomimetic organocatalyst,

which mediates the oxidative coupling of primary amines. Without any metal cocatalyst or additives, the methodgives aceess to diverse cross-coupling imines, or 1,2-disubstituted benzimidazole derivatives in the presence of $o$-aminoanilines. This method constitutes an appropriate illustration of the potential of "second order" biomimicry in terms of atom economy, while preserving the benefit of the eco-friendly nature of the bioinspired catalytic processes. A rational application of this concept should allow the discovery of efficient catalysts generated from simple, low-cost precursors, introducing new opportunities in green chemistry.

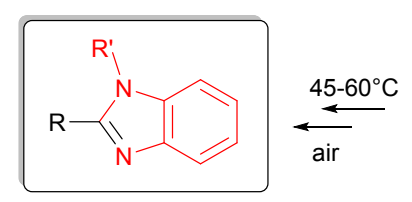

25a-o

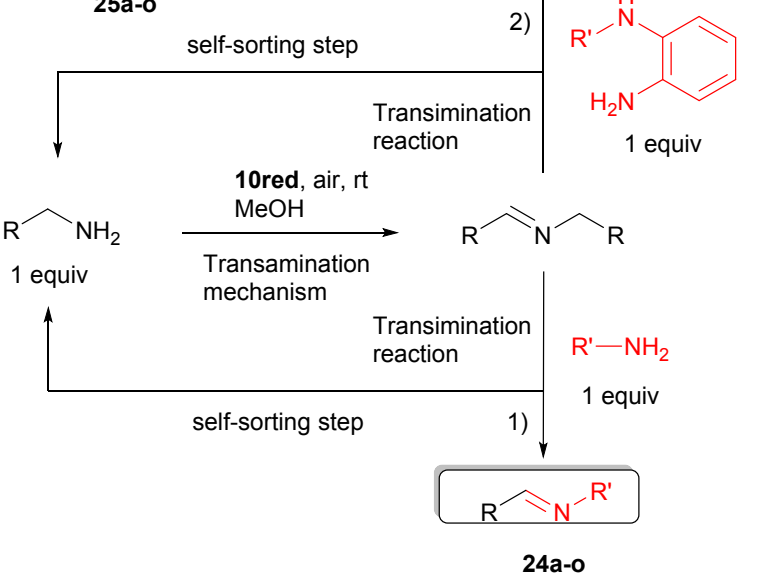

24a-o

Scheme 9 Biomimetic cascade reaction sequence affording crosscoupled imines 24a-o or 1,2-disubstituted benzimidazoles 25a-o.

\section{Experimental}

Isolation of the [5+2] cycloaddition redox products 18red and 19red in the course of the aerobic oxidation of benzylamine 15 mediated by 17 red

Benzylamine 15 ( $2 \mathrm{mmol}$ ) and pyrogallol derivative $17 \mathrm{red}(0.5 \mathrm{mmol})$ were mixed in $\mathrm{MeOH}(25 \mathrm{~mL})$, under ambient air. The reaction mixture was stirred at room temperature. The progress of the reaction was monitored by ${ }^{1} \mathrm{H}$ NMR spectroscopy. When $30 \%$ of benzylamine 15 was converted into $N$-benzylidene benzylamine 16, the reaction was stopped by addition of dry ice. After evaporation of the solvent under reduced pressure at $30^{\circ} \mathrm{C}$, the residue was purified by column chromatography (toluene-acetone, $90 / 10 \mathrm{v} / \mathrm{v}$ ) on silica gel, to afford the [5+2] cycloaddition redox intermediates 18red $(0.025$ $\mathrm{mmol}$ ) and 19red $(0.075 \mathrm{mmol})$ in 5 and $15 \%$ yields, respectively. Caution: particular attention is required during the column chromatography which has to be realized quickly to minimize the aerobic oxidation of products $18 \mathrm{red}$ and $19 \mathrm{red}$ to melanin-like polymers. 


\section{1,7-dibenzyl-2,3,4,6-tetrahydroxy-5H-benzo[7]annulen-5-one}

(18red). Orange solid (10 mg, $5 \%$ ): $\mathrm{mp} 172-176^{\circ} \mathrm{C} ; R_{\mathrm{f}}=0.5$ (tolueneacetone, 80/20 v/v); ${ }^{1} \mathrm{H}$ NMR (300 MHz, DMSO D6) $\delta 4.03(\mathrm{~s}, 2 \mathrm{H}), 4.32$ $(\mathrm{s}, 2 \mathrm{H}), 6.77(\mathrm{~d}, J=12.4 \mathrm{~Hz}, 1 \mathrm{H}), 7.08-7.26(\mathrm{~m}, 10 \mathrm{H}), 7.49(\mathrm{~d}, J=12.4$ $\mathrm{Hz}, 1 \mathrm{H}), 15.57$ (s, 1H, D $\mathrm{O}$ exchanged); ${ }^{13} \mathrm{C}\left\{{ }^{1} \mathrm{H}\right\}$ NMR (75 MHz, DMSO D6) $\delta 31.4,39.1,115.9,117.3,126.1,126.7,128.26(\mathrm{x} 2), 128.33$, 128.68, 128.74 (x2), 128.88 (x2), 129.1 (x2), 130.1, 130.8, 134.8, 140.1, 141.0, 150.5, 151.2, 152.6, 182.1; HRMS (ESI-) $\mathrm{m} / \mathrm{z}$ calcd for $\mathrm{C}_{25} \mathrm{H}_{20} \mathrm{O}_{5}[\mathrm{M}-\mathrm{H}]^{-}$399.1232. Found 399.1238. 1D and 2D NMR spectra for compound 18red are reported in the ESI. Key HMBC correlations are shown in Chart 2.

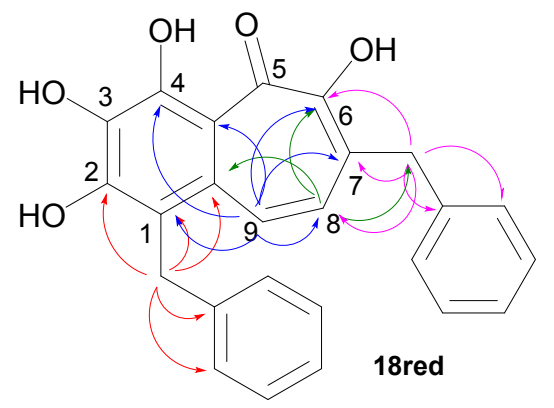

Chart 2 Key HMBC correlations of compound 18red.

(6R,9R)-1,7,11-tribenzyl-2,3,4,6-tetrahydroxy-6,9-dihydro-5H-6,9(epiminomethano)benzo[7]annulene-5,10-dione (19red). Yellow crystal ( $40 \mathrm{mg}, 15 \%): \mathrm{mp} 244-248^{\circ} \mathrm{C} ; R_{\mathrm{f}}=0.4$ (toluene-acetone, $80 / 20$ $\mathrm{v} / \mathrm{v}$ ); ${ }^{1} \mathrm{H}$ NMR (400 MHz, $\left.\mathrm{CD}_{3} \mathrm{OD}\right) \delta 3.40-3.48(\mathrm{~m}, 2 \mathrm{H}), 3.99(\mathrm{~d}, J=16.3$ $\mathrm{Hz}, 1 \mathrm{H}), 4.48-4.56(\mathrm{~m}, 3 \mathrm{H}), 4.82(\mathrm{~m}, 1 \mathrm{H}), 5.54(\mathrm{~d}, J=7.0 \mathrm{~Hz}, 1 \mathrm{H}), 6.97$ $(\mathrm{m}, 2 \mathrm{H}), 6.96-7.189(\mathrm{~m}, 13 \mathrm{H}) ;{ }^{13} \mathrm{C}\left\{{ }^{1} \mathrm{H}\right\}$ NMR $\left(100 \mathrm{MHz}, \mathrm{CD}_{3} \mathrm{OD}\right) \delta 30.3$, $35.2,43.2,48.3,87.8,105.2,118.6,125.5,125.9,126.8,127.5$ (x2), $127.78(x 2), 127.82(x 2), 127.9(x 2), 128.0(x 2), 128.7,128.8(x 2)$, 131.6, 131.8, 137.5, 137.6, 141.1, 145.6, 151.2, 153.5, 171.1, 191.9; HRMS (ESI-) $\mathrm{m} / \mathrm{z}$ calcd for $\mathrm{C}_{33} \mathrm{H}_{27} \mathrm{NO}_{6}[\mathrm{M}-\mathrm{H}]^{-}$532.1760. Found 532.1772. X-Ray analysis: A yellow crystal of $0.27 \times 0.22 \times 0.05 \mathrm{~mm}$, crystallized from a mixture toluene/methanol was used. Empirical formula $\mathrm{C}_{33} \mathrm{H}_{27} \mathrm{NO}_{6}, \mathrm{M}=533.55, \mathrm{~T}=100(2) \mathrm{K}$. Triclinic system, space group P-1, $Z=4, a=12.6327(6) \AA, b=15.2434(7) \AA, c=15.9800(7) \AA$, $\alpha=102.027(2)^{\circ}, \beta=105.432(2)^{\circ}, \gamma=112.595(2)^{\circ}, V=2566.4(2) \AA^{3}$, $d_{\text {calc }}=1.381 \mathrm{~g} \mathrm{~cm}^{-3}, \mathrm{~F}(000)=1120, \mu=0.776 \mathrm{~mm}^{-1}, \lambda($ CuK $\alpha)=$ $1.54178 \AA .77250$ intensity data were collected with a VENTURE PHOTON100 CMOS Bruker diffractometer (Cu-K $\alpha$ radiation) controlled by APEX3 software package, giving 9064 unique reflections. Refinement of 743 parameters on $F^{2}$ led to $R_{1}(F)=0.0375$ calculated with 7934 observed reflections as $I \geq 2$ sigma $(I)$ and $w R_{2}\left(F^{2}\right)=0.1045$ considering all the 9064 data. Goodness of fit $=$ 1.011. CCDC deposition number: 1965257. 1D and 2D NMR spectra for compound 19red are reported in the ESI. Key HMBC correlations are shown in Chart 3.

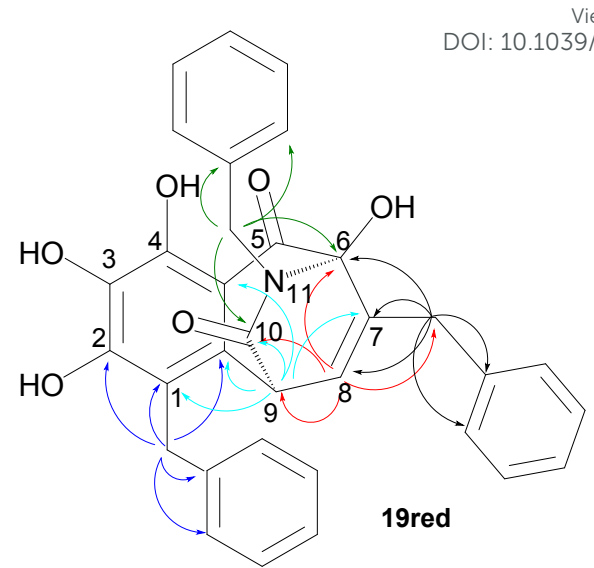

Chart 3 Key HMBC correlations of compound 19red.

Representative experimental procedure for the organocatalyzed aerobic oxidative cross-coupling of two primary amines

Equimolar amounts of benzylamine $(2.5 \mathrm{mmol})$ and 1ethylpropylamine $(2.5 \mathrm{mmol})$, pyrogallol $10 \mathrm{red}(0.2 \mathrm{mmol}, 8 \mathrm{~mol} \%$, corresponding to the generation of $4 \mathrm{~mol} \%$ of purpurogallin 11red) were mixed in $\mathrm{MeOH}(10 \mathrm{~mL})$, under ambient air. The reaction mixture was stirred at room temperature for $24 \mathrm{~h}$. The progress of the reaction was monitored by ${ }^{1} \mathrm{H}$ NMR spectroscopy. After completion of the reaction, the solvent was evaporated, at room temperature, to give the cross-coupling imine product 24 a as an almost pure product, which was further purified by washing through a small pad of base-washed silica (eluent: $1 / 2$ petroleum ether/ethyl acetate $+2 \%$ triethylamine). Caution: particular attention is required during the column chromatography which has to be realized quickly to avoid the hydrolysis of the cross-coupled imine to aldehyde. The above procedure is generally representative for all the products shown in Table 1. Any deviations from this protocol are specified in the footnotes of Table 1.

X-Ray analysis of imine $\mathbf{2 4 j}$. A colorless crystal of $0.23 \times 0.19 \times 0.04$ $\mathrm{mm}$, crystallized from methanol was used. Empirical formula $\mathrm{C}_{17} \mathrm{H}_{17} \mathrm{~N}, \mathrm{M}=235.1, \mathrm{~T}=100(2) \mathrm{K}$. Triclinic system, space group $\mathrm{P}$ $1, \mathrm{Z}=2, \quad a=5.6742(2) \AA, \quad b=8.7921(4) \AA, c=13.5713(5) \AA, \alpha=$ 103.259(1) ${ }^{\circ}, \beta=95.099(1)^{\circ}, \gamma=95.624(1)^{\circ}, V=651.48(4) \AA^{3}, d_{\text {calc }}=$ $1.200 \mathrm{~g} \mathrm{~cm}^{-3}, \mathrm{~F}(000)=252, \mu=0.526 \mathrm{~mm}^{-1}, \lambda(\mathrm{CuK} \alpha)=1.54178 \AA$. 21496 intensity data were collected with a VENTURE PHOTON100 CMOS Bruker diffractometer (CU-K $\alpha$ radiation) controlled by APEX3 software package, giving 2166 unique reflections. Refinement of 166 parameters on $\mathrm{F}^{2}$ led to $R_{1}(\mathrm{~F})=0.0439$ calculated with 1995 observed reflections as $I \geq 2$ sigma $(I)$ and $w R_{2}\left(F^{2}\right)=0.1122$ considering all the 2166 data. Goodness of fit $=1.072$. CCDC deposition number: 1981805. 
General experimental procedure for the organocatalyzed aerobic oxidative coupling reaction affording 1,2-disubstituted benzimidazoles

Equimolar amounts of primary amine $(1.25 \mathrm{mmol})$ and $\mathrm{N}$ substituted-o-aminoaniline $(1.25 \mathrm{mmol})$ with pyrogallol $10 \mathrm{red}(0.1$ $\mathrm{mmol}, 8 \mathrm{~mol} \%$, which corresponds to the generation of $4 \mathrm{~mol} \%$ of purpurogallin 11red), were mixed in $\mathrm{MeOH}(25 \mathrm{~mL})$, in an air atmosphere. The reaction mixture was stirred at $60^{\circ} \mathrm{C}$ for $24 \mathrm{~h}$. Then, an additional aliquot of $0.025 \mathrm{mmol}$ of 10red (2 mol\%) was introduced into the reaction mixture and the reaction was continued for $36 \mathrm{~h}$. The solvent was then removed by evaporation under reduced pressure, and the residue was purified by column chromatography on silica gel (eluent: $1 / 1$ petroleum ether/ethyl acetate) to afford 1,2-disubstituted benzimidazoles 25a-0. The above procedure is generally representative for all benzimidazoles shown in Table 2. Any deviations from this protocol are specified in the footnotes of Table 2 .

X-Ray analysis of 1,2-benzimidazole $25 \mathrm{~d}$. A colorless crystal of 0.21 $\times 0.16 \times 0.10 \mathrm{~mm}$, crystallized from a mixture chloroform/petroleum ether was used. Empirical formula $\mathrm{C}_{16} \mathrm{H}_{14} \mathrm{~N}_{2}, \mathrm{M}=234.29, \mathrm{~T}=100(2)$ K. Triclinic system, space group P-1, $Z=4, \quad a=10.3880(4) \AA, \quad b=10.8621(4) \AA, \quad c=11.9356(4) \AA, \quad \alpha=$ 103.368(1) ${ }^{\circ}, \beta=111.316(21)^{\circ}, \gamma=90.267(1)^{\circ}, V=1214.77(8) \AA^{3}, d_{\text {calc }}$ $=1.281 \mathrm{~g} \mathrm{~cm}^{-3}, \mathrm{~F}(000)=496, \mu=0.591 \mathrm{~mm}^{-1}, \lambda($ CuK $\alpha)=1.54178 \AA \AA$. 29618 intensity data were collected with a VENTURE PHOTON100 CMOS Bruker diffractometer (Cu-K $\alpha$ radiation) controlled by APEX3 software package, giving 3491 unique reflections. Refinement of 325 parameters on $F^{2}$ led to $R_{1}(F)=0.0314$ calculated with 3328 observed reflections as $I \geq 2$ sigma $(I)$ and $w R_{2}\left(F^{2}\right)=0.784$ considering all the 3491 data. Goodness of fit $=1.099$. CCDC deposition number: 1981802

\section{Conflicts of interest}

There are no conflicts to declare.

\section{Acknowledgements}

We thank CNRS and Paris Descartes University for financial support. Pascale Leproux is acknowledged for running high resolution mass spectra. The authors also wish to thank Regis Guillot (ICMMO - Université Paris Saclay) for collecting the crystallographic data.

\section{Notes and references}

1 For selected reviews or perspectives, see: (a) L. Marchetti and M. Levine, ACS catal. 2011, 1, 1090; (b) C. K. Prier and F. H. Arnold, J. Am. Chem. Soc. 2015, 137, 13992; (c) R. A. Sheldon and J. M. Woodley, Chem. Rev. 2018, 118, 801; (d) R. A. Sheldon and D. Brady, ChemSusChem. 2019, 12, 2859.

2 For selected reviews, see: (a) O. Pamies, M. Dieguez and J.-E. Bäckvall, Adv. Synth. Catal. 2015, 357, 1567; (b) F. Schwizer, Y. Okamoto, T. Heinisch, Y. Gu, M. M. Pellizzoni, V. Lebrun, R.
Reuter, V. Köhler, J. C. Lewis, T. R. Ward, Chem, Rev. 2018 , 118, 142; (c) M. T. Reetz, Acc. Chem. Res, 2019,352, 336 191 E EA N. Mirts, A. Bhagi-Damodaran and Y. Li, Acc. Chem. Res. 2019, 52, 935.

3 For selected reviews, see: (a) J. Piera and J. E. Bäckvall, Angew. Chem. Int. Ed. 2008, 47, 3506; (b) L. Que Jr and W. B. Tolman, Nature, 2008, 455, 333; (c) L. Que Jr and W. N. Oloo, Acc. Chem. Res. 2015, 48, 2612; (d) M. M. Pereira, L. D. Dias and M. J. F. Calvete, ACS catal. 2018, 8, 10784.

4 For selected reviews, see: (a) J. P. Klinman, Chem. Rev. 1996, 96, 2541; (b) J. P. Klinman, Biochim. Biophys. Acta, 2003, 1647, 131; (c) B. J. Brazeau, B. J. Johnson and C. M. Wilmot, Arch. Biochem. Biophys., 2004, 428, 22; (d) P. Matyus, B. DajkaHalasz, A. Földi, N. Haider, D. Barlocco, K. Magyar, Curr. Med. Chem. 2004, 11, 1285; (e) M. Strolin Benedetti, K. F. Tipton and R. Whomsley, Fondam. Clin. Pharmacol., 2007, 21, 467; (f) A. Boobis, J. B. Watelet, R. Whomsley, M. Strolin Benedetti, P. Demoly and K. T. Tipton, Drug Metab. Rev., 2009, 41, 486.

5 S. M. Janes, D. Mu, D. Wemmer, A. J. Smith, S. Kaur, D. Maltby, A. L. Burlingame and J. P. Klinman, Science, 1990, 248, 981.

6 S. Suzuki, T. Okajima, K. Tanizawa and M. Mure, Cofactors of amine oxidases. Copper ion and its substitution and the 2,4,5trihydroxyphenylalanine quinone. In Copper Amine Oxidases. Structures, Catalytic Mechanisms, and Role in Pathophysiology, ed. G. Floris and B. Mondovi, CRC Press, Taylor and Francis Group Publishing, New York, 2009; p. 19.

7 (a) M. Mure, S. A. Mills and J. P. Klinman, Biochemistry, 2002, 41, 9269-9278; (b) M. Mure, Acc. Chem. Res., 2004, 37, 131; (c) J. L. Dubois and J. P. Klinman, Arch. Biochem. Biophys., 2005, 433, 255; (d) J. P. Klinman and F. Bonnot, Chem. Rev. 2014, 114, 4343.

8 For selected examples, see: (a) Y. Lee and L. M. Sayre, J. Am. Chem. Soc., 1995, 117, 3096; (b) M. Mure and J. P. Klinman, J. Am. Chem. Soc., 1995, 117, 8698; (c) M. Mure and J. P. Klinman, J. Am. Chem. Soc., 1995, 117, 8707; (d) Y. Lee and L. M. Sayre, J. Am. Chem. Soc., 1995, 117, 11823; (e) K. Q. Ling, J. Kim and L. M. Sayre, J. Am. Chem. Soc., 2001, 123, 9606; (f) M. Mure, S. X. Wang and J. P. Klinman, J. Am. Chem. Soc., 2003, 125, 6113.

9 For reviews or perspectives, see: (a) M. Largeron and M.-B. Fleury, Science, 2013, 339, 43; (b) A. E. Wendlandt and S. S. Stahl, Angew. Chem. Int. Ed. 2015, 54, 14638; (c) M. Largeron, Org. Biomol. Chem. 2017, 15, 4722; (d) R. Zhang and S. Luo, Chin. Chem. Lett. 2018, 29, 1193; (e) M. Largeron, Pure Appl. Chem. 2019, DOI: 10.1515/pac-2019-0107.

10 For selected recent examples, see: (a) A. E. Wendlandt and S. S. Stahl, Org. Lett. 2012, 14, 2850; (b) M. Largeron and M.-B. Fleury, Angew. Chem. Int. Ed. 2012, 51, 5409; (c) D. V. Jawale, E. Gravel, E. Villemin, N. Shah, V. Geersten, I. N. N. Namboothiri and E. Doris, Chem. Commun. 2014, 50, 15251; (d) M. Largeron and M.-B. Fleury, Chem.-Eur. J., 2015, 21, 3815; (e) Y. Goriya, H. Y. Kim and K. Oh, Org. Lett. 2016, 18, 5174; (f) R. Jangir, M. Ansari, D. Kaleeswaran, G. Rajaraman, M. Palaniandavar and R. Murugavel, ACS Catal. 2019, 9, 10940.

11 For selected recent examples, see: (a) K. M. H. Nguyen and M. Largeron, Chem. -Eur. J., 2015, 21, 12606; (b) M. A. Leon, X. Liu, J. H. Phan and M. D. Clift, Eur. J. Org. Chem. 2016, 2016, 4508; (c) K. M. H. Nguyen and M. Largeron, Eur. J. Org. Chem. 2016, 2016, 1025; (d) R. Zhang, Y. Qin, L. Zhang and S. Luo, Org. Lett. 2017, 19, 5629; (e) K. Kim, H. Y. Kim and K. Oh, Org. Lett. 2019, 21, 6731; (f) S. A. Pawar, A. N. Chand, and A. Vijay Kumar, ACS Sustainable Chem. Eng. 2019, 7, 8274; (g) Q. Yang, Y. Zhang, W. Zeng, Z.-C. Duan, X. Sang and D. Wang, Green Chem. 2019, 21, 5683.

12 (a) R. Zhang, Y. Qin and S. Luo, J. Org. Chem. 2019, 84, 2542. (b) B. Li, A. E. Wendlandt and S. S. Stahl, Org. Lett. 2019, 21, 1176. 
13 T. Si, H. Y. Kim and K. Oh, ACS catal. 2019, 9, 9216.

14 (a) Y. Qin, L. Zhang, J. Lv, S. Luo and J.-P. Cheng, Org. Lett. 2015, 17, 1469. (b) G. Golime, G. Bogonda, H. Y. Kim and K. Oh, ACS catal. 2018, 8, 4986.

15 (a) H. Yuan, W.-J. Yoo, H. Miyamura and S. Kobayashi, J. Am. Chem. Soc. 2012, 134, 13970. (b) A. E. Wendlandt and S. S. Stahl, J. Am. Chem. Soc. 2014, 136, 506. (c) A. E. Wendlandt and S. S. Stahl, J. Am. Chem. Soc. 2014, 136, 11910. (d) D. V. Jawale, E. Gravel, N. Shah, V. Dauvois, H. Li, I. N. N. Namboothiri and E. Doris, Chem. - Eur. J. 2015, 21, 7039.

16 S. D. McCann, J. -P. Lumb, B. A. Arndtsen and S. S. Stahl, ACS Cent. Sci. 2017, 3, 314.

17 M. Largeron and M. -B. Fleury, Chem. -Eur. J. 2017, 23, 6763.

18 (a) W. Dürckheimer and E. F. Paulus, Angew. Chem. Int. Ed. 1985, 24, 224; (b) P. Ellerbrock, N. Armanino, M.K. Ilg, R. Webster and D. Trauner, Nat. Chem. 2015, 7, 879; (c) A. J. E. Novak, C. E. Grigglestone and D. Trauner, J. Am. Chem. Soc. 2019, 141, 15515.

19 Y. Wang, J. P. Park, S. H. Hong and H. Lee, Adv. Mater. 2016, 28, 9961.

20 (a) M. Largeron and M.-B. Fleury, J. Org. Chem., 2000, 65, 8874; (b) M. Largeron, A. Neudörffer and M.-B. Fleury, Angew. Chem. Int. Ed., 2003, 42, 1026; (c) M. Largeron, A. Chiaroni and M.-B. Fleury, Chem. - Eur. J., 2008, 14, 996.

21 (a) H. Miyabe, Y. Yamaoka, Y. Takemoto, Synlett 2004, 2597; (b) H. Miyabe, Y. Yamaoka, Y. Takemoto, J. Org. Chem. 2006, 71, 2099.

22 For selected recent examples, see: (a) A. T. Murray, R. King, J. V. G. Donnelly, M. J. H. Dowley, F. Tuna, D. Sells, M. P. John and D. R. Carbery, ChemCatChem 2016, 8, 510; (b) Y. R. Girish, R. Biswas and M. De, Chem.-Eur. J. 2018, 24, 13871; (c) R.E. Rodriguez-Lugo, M. A. Chacon-Teran, S. De Leon, M. Vogt, A. J. Rosenthal and V.R. Landaeta, Dalton Trans. 2018, 47, 2061 (d) S. Hazra, P. Pilania, M. Deb, A. K. Kushawaha and A. J. Elias, Chem.-Eur. J. 2018, 24, 15766; (e) R. Brisar, F. Unglaube, D. Hollmann, H. Jiao and E. Esteban, J. Org. Chem. 2018, 83 13481; (f) C.-P. Dong, A. Uematsu, S. Kumazawa, Y. Yamamoto, S. Kodama, A. Nomoto, M. Ueshima and A. Ogawa, J. Org. Chem. 2019, 84, 11562.

23 For another example where $\mathrm{MeOH}$ was shown to be an efficient solvent for enhancing the quinone reactivity, see: $C$. W. Anson, S. Ghosh, S. Hammes-Schiffer and S. S. Stahl, J. Am. Chem. Soc. 2016, 138, 4186.

24 D. Prat, A. Wells, J. Hayler, H. Sneddon, C. R. McElroy, S. AbouShehada and P. J. Dunn, Green Chem. 2016, 18, 288.

25 E. Vitaku, D.T. Smith and J. T. Njardarson, J. Med. Chem. 2014, 57, 10257.

26 For reviews, see: (a) L.C. R. Carvalho, E. Fernandes and M. M. B. Marques, Chem. - Eur. J. 2011, 17, 12544 and references therein; (b) S. Singhal, P. Khanna, S. S. Panda and L. Khanna, J. Heterocyclic Chem. 2019, 56, 2702. For selected recent examples, see: (c) M. Pizzeti, E. De Luca, E. Petricci, A. Porcheddu and M. Taddei, Adv. Synth. Catal. 2012, 354, 2453; (d) N. T. Jui and S. L. Buchwald, Angew. Chem. Int. Ed. 2013, 52, 11624; (e) S. Kumar Alla, R. Kiran Kumar, P. Sadhu and T. Punniyamurthy, Org. Lett. 2013, 15, 1334; (f) D. Kommi, P. D. Jadhavar, D. Kumar and A. K. Chakraborti, Green Chem. 2013 15, 798; (g) J. -P. Lin, F. -H. Zhang, and Y. -Q. Long, Org. Lett. 2014, 16, 2822; (h) L. Q. Tran, J. Li and L. Neuville, J. Org. Chem. 2015, 80, 6102; (i) X. Shi, J. Guo, J. Liu, M. Ye and Q. Xu, Chem. - Eur. J. 2015, 21, 9988; (j) H. Sharma, N. Kaur, N. singh and D. O. Jang, Green Chem. 2015, 17, 4263; (k) Y.- L. Lai, J. -S. Ye and J. -M. Huang, Chem. -Eur. J. 2016, 22, 5425; (I) J. Xia, X. Yang, Y. Li and X. li, Org. Lett. 2017, 19, 3243; (m) C. Xie, X. Han, J. Gong, D. Li and C. Ma, Org. Biomol. Chem. 2017, 15, 5811. (n) T. Liang, Z. Tan, H. Zhao, X. Chen, H. Jiang and M. Zhang, ACS Catal. 2018, 8, 2242; (o) A. Bera, M. Sk, K. Sigh and D. Banerjee, Chem. Commun. 2019, 55, 5958; (p) G. Lu, N. Luo, F.
Hu, Z. ban, Z. Zhan and G.-S. Huang, Adv. Synth Catal. 2019, DOI:10.1002/adsc.201901161.

DOI: 10.1039 /C9GC03992A

27 For a recent review, see: M. Largeron and K. M. H. Nguyen, Synthesis, 2018, 50, 241 and references therein.

28 B. Xu, J. -P. Lumb and B. A. Arndtsen, Angew. Chem. Int. Ed. 2015, 54, 4208

29 For a review, see: M. E. Belowich and J. F. Stoddart, Chem. Soc. Rev. 2012, 41, 2003. 


\section{Table of contents entry}

Low-cost pyrogallol precatalyst undergoes an oxidative selfprocessing step for delivering the active organocatalyst in situ through a dual biomimetic process.

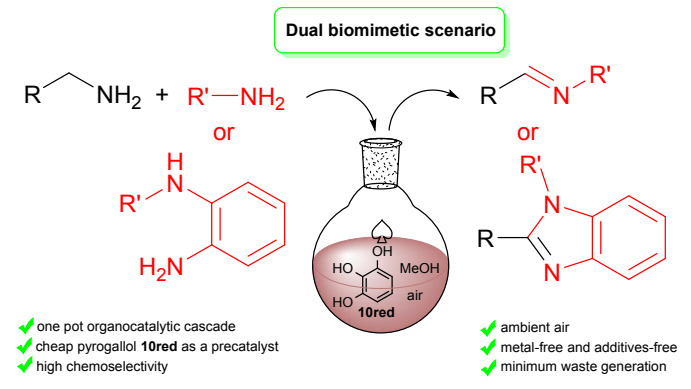

